\title{
ANALISIS FINANSIAL USAHA KERAMBA JARING APUNG DI PERUSAHAAN PERSEORANGAN DOBRO
}

\author{
Finansicial Analysis Effort Floating Cages In A Private Company \\ 'Dobro' \\ Donny Suryanto1) dan Eko Sumartono ${ }^{2)}$ \\ 1) Konsultan Pendidikan di Brunai Darussalam \\ ${ }^{2)}$ Staff Pengajar Jurusan SOSEK Fakultas Pertanian Universitas Bengkulu \\ Email :eko_vixion@unib.ac.id
}

\begin{abstract}
This research is intended to know factors influencing fish production, financial performance and business security of private company Dobro. Data which are analyzed including production data (production, feed, seed and worker) for fish production factors analysis, balancing and profit/loss statement 2006 - 2009 for financial performance and business security analysis. The production factors analysis in this research uses regression method with Cobb-Douglas production function approach. The financial performance and business security use financial statement comparison and ratio analysis. Ratios that be researched are liquidity (ratios that be researched are current and quick ratio), solvability (ratios that be researched are total debt to total asset ratio and total debt to equity ratio), efficiency (ratios that be researched are inventory turnover, account receivable turnover, fixed asset turnover and total asset turnover) and profitability ratio (ratios that be researched are gross profit margin, operating profit margin, net profit margin and return on investment). Business security analysis use Altman $Z^{\prime \prime}$ score to detect company position in Altman area of bankruptcy. The result of this research could be concluded that fish production is simultaneous and individually influenced by feed, seed and worker. Financial analysis shows company liquidity in good condition with positive average growth values. Solvability is also in good condition with negative average growth values. Commonly efficiency and profitability have normal values, but have negative average growth value. Based Altman Z" score, company exists in area which secure from bankruptcy threat.
\end{abstract}

Keywords: Production, financial, bankruptcy

\section{PENDAHULUAN}

Menurut Proyek Pengkajian Teknologi Pertanian Yogyakarta (1997) diterangkan bahwa budidaya ikan dalam keramba jaring apung (KJA) dikenal khalayak umum pada tahun 1974 di waduk Jatiluhur, Purwakarta, Jawa Barat. Sedangkan penerapan budidaya ikan dalam KJA secara intensif baru 
berkembang pada tahun 1986 di waduk Saguling. Dan pada tahun 1996 mulai diperkenalkan budidaya ikan nila merah di waduk Sermo, Kulonprogo.

Menurut Sukadi MF dkk (1989) dalam Khairuman dan Sudenda (2002) dijelaskan bahwa kriteria kualitas air budidaya ikan dalam keramba jaring apung di danau atau waduk adalah seperti yang tercantum pada Tabel 1.

Tabel 1. Kriteria Kualitas Fisika Dan Kimia Air Untuk Budidaya Ikan Dalam Keramba Jaring Apung Di Danau Atau Waduk Beserta Satuan Dan Nilai Ambang Batasnya.

\begin{tabular}{|c|c|c|c|}
\hline No & Kriteria & Satuan & Nilai Batas \\
\hline \multicolumn{4}{|c|}{ Parameter Fisika } \\
\hline 1 & Suhu & ${ }^{\circ} \mathrm{C}$ & $20-30$ \\
\hline 2 & Total padatan terlarut & $\mathrm{mg} / 1$ & $\leq 2.000$ \\
\hline 3 & Kecerahan & $\mathrm{cm}$ & $\geq 45$ \\
\hline \multicolumn{4}{|c|}{ Parameter Kimia } \\
\hline 1 & pH (derajat keasaman) & - & $6-9$ \\
\hline 2 & Oksigen terlarut & $\mathrm{mg} / 1$ & maksimum 8 jam/hari, minimal \\
\hline 3 & Karbondioksida bebas & $\mathrm{mg} / 1$ & $\leq 15$ \\
\hline 4 & Amoniak & $\mathrm{mg} / \mathrm{l}$ & $\leq 0,016$ \\
\hline 5 & Nitrit & $\mathrm{mg} / 1$ & $\leq 0,2$ \\
\hline 6 & Tembaga $(\mathrm{Cu})$ & $\mathrm{mg} / 1$ & $\leq 0,02$ \\
\hline 7 & Seng $(\mathrm{Zn})$ & $\mathrm{mg} / 1$ & $\leq 0,02$ \\
\hline 8 & Merkuri (Hg) & $\mathrm{mg} / 1$ & $\leq 0,002$ \\
\hline 9 & Timbal $(\mathrm{Pb})$ & $\mathrm{mg} / 1$ & $\leq 0,3$ \\
\hline 10 & Klorin bebas $(\mathrm{Cl})$ & $\mathrm{mg} / 1$ & $\leq 0,003$ \\
\hline 11 & Fenol & $\mathrm{mg} / 1$ & $\leq 0,001$ \\
\hline 12 & Sulfida (S) & $\mathrm{mg} / 1$ & $\leq 0,002$ \\
\hline 13 & Kadmium (Cd) & $\mathrm{mg} / 1$ & $\leq 0,01$ \\
\hline 14 & Fluorida & $\mathrm{mg} / 1$ & $\leq 1,5$ \\
\hline 15 & Arsenik (As) & $\mathrm{mg} / 1$ & $\leq 1$ \\
\hline 16 & Selenium (Se) & $\mathrm{mg} / 1$ & $\leq 0,05$ \\
\hline 17 & Krom heksavalen $(\mathrm{Cr}+6)$ & $\mathrm{mg} / 1$ & $\leq 0,05$ \\
\hline 18 & Sianida $(\mathrm{Cn})$ & $\mathrm{mg} / 1$ & $\leq 0,02$ \\
\hline 19 & Minyak dan lemak & $\mathrm{mg} / 1$ & $\leq 1$ \\
\hline
\end{tabular}

Untuk menjaga kelestarian waduk, areal perairan yang boleh dikembangkan untuk pengembangan KJA hanya 2\% dari luasan waduk. Pengembangan KJA yang melampaui batas kemampuan waduk dan kurang mengindahkan kaidah-kaidah budidaya ikan akan mengakibatkan kematian masal dan pencemaran lingkungan perairan waduk (Proyek Pengkajian Teknologi Pertanian Yogyakarta, 1997).

Berdasarkan penelitian perikanan di waduk Kedung Ombo yang dilakukan tim peneliti dari Jurusan Perikanan, Fakultas Pertanian, Universitas Gadjah Mada, Yogyakarta (1992) dipaparkan bahwa pemeliharaan ikan dalam

2 | Donny Suryanto dan Eko Sumartono, Analisis Finansial Usaha ... 
keramba jaring apung ukuran $7 \times 7 \times 3,5 \mathrm{~m} 3$ dengan ukuran mata jaring (mesh size) 0,75 inchi dapat dilakukan 3 kali dalam setahun (masing-masing selama 3 bulan dengan persiapan 1 bulan). Pertumbuhan ikan mas selama 3 bulan dapat mencapai 4,5 kali lipat dan ikan nila merah mencapai 5 kali lipat dari berat penebaran. Ukuran individu ikan mas maupun nila merah pada waktu panen adalah 200-300 gram/ekor. Feed Convertion Ratio (Rasio Konversi Pakan) ratarata untuk ikan mas mencapai 2 dan ikan nila merah 1,5. B/C ratio ikan mas mencapai 1,13 dan ikan nila merah 1,11. Biaya untuk pakan ikan mas sebesar $56,07 \%$ dan ikan nila merah 60,93\% dari biaya operasional.

Kemudian, pada pada salah satu kesimpulan tesis "Strategi Pemasaran Nila Merah Hasil Budidaya Sistem Keramba Jaring Apung di Kabupaten Sragen" yang disusun oleh Suciyati (2005) dijelaskan bahwa dengan analisis biaya dan pendapatan usaha diketahui bahwa usaha budidaya nila merah sistem KJA di waduk Kedung Ombo, Kabupaten Sragen menghasilkan RCR (Return Cost Ratio) sebesar 2,33, artinya bahwa secara finansial unit usaha ini mampu menghasilkan laba karena nilai RCR-nya lebih besar dari standar (RCR>2). Meskipun keuntungan yang dihasilkan tidak terlalu tinggi namun masih dapat ditingkatkan dengan menggunakan strategi pemasaran yang tepat.

Perusahaan perseorangan pada umumnya mempunyai sifat kerahasiaan atas laporan keuangan atau segala informasi yang berhubungan dengan masalah keuangan perusahaan dengan alasan supaya tidak dapat dimanfaatkan oleh kompetitor bisnis. Oleh karena hal tersebut, banyak sekali pemilik tunggal perusahaan perorangan merasa tidak perlu membuat laporan keuangan beserta analisisnya. Kondisi inilah yang menyebabkan pemilik tunggal perusahaan perseorangan tidak dapat memantau kondisi kesehatan perusahaannya dari waktu ke waktu dan hal tersebut menyebabkan pemilik tidak mempunyai landasan yang kuat dalam membuat strategi perusahaan. Bahkan akan menjadi sangat membahayakan ketika pemilik perusahaan perseorangan tidak menyadari bahwa perusahaannya sedang menuju kebangkrutan.

Berdasarkan hasil penelitian yang dilakukan Darmawi (2003) pada USP Swamitra KUD Godean dapat diketahui bahwa kinerja keuangan unit usaha tersebut mengalami peningkatan yang baik pada aspek likuiditas. Hal ini berarti bahwa perusahaan mampu memenuhi kewajiban jangka pendeknya. Sedangkan solvabilitas USP Swamitra walaupun dalam perkembangannya menunjukkan trend yang baik namun masih dalam kondisi yang kurang baik karena proporsi hutang yang sangat tinggi dalam struktur permodalan dan masih kecilnya modal sendiri, sehingga kemampuan untuk memenuhi kewajiban jangka panjangnya sangat mengkhawatirkan. Profitabilitas USP Swamitra sangat baik terlihat dari keuntungan yang selalu meningkat, namun bad debt ratio (BDR) atau pinjaman yang bermasalah menunjukkan kondisi yang kurang sehat.

Gill dan Chatton (2008) mendefinisikan laporan keuangan sebagai ringkasan dari suatu pencatatan atau ringkasan dari transaksi-transaksi 
keuangan yang terjadi selama tahun buku yang bersangkutan. Sedangkan menurut Myer pada bukunya Financial Statement Analysis dalam Munawir (2004) menjelaskan bahwa yang dimaksud dengan laporan keuangan adalah "dua daftar yang disusun oleh akuntan pada akhir periode untuk suatu perusahaan. Kedua daftar itu adalah daftar neraca atau daftar posisi keuangan dan daftar pendapatan atau daftar rugi laba. Akhir-akhir ini sudah menjadi kebiasaan bagi kebanyakan perseroan untuk menambahkan daftar ketiga yaitu daftar surplus atau daftar laba yang tak dibagikan (laba yang ditahan)"

Menurut Swasta (1995) bahwa terdapat dua metode analisa laporan keuangan yaitu metode vertikal dan metode horizontal atau tren berkala. Metode vertikal adalah analisa elemen-elemen laporan keuangan pada satu periode tertentu. Sedangkan metode horizontal adalah metode analisis laporan keuangan antara dua periode atau lebih. Metode analisis horizontal (dinamis) adalah metode analisis yang dilakukan dengan cara membandingkan laporan keuangan untuk beberapa tahun (periode), sehingga dapat diketahui perkembangan dan kecenderungannya.

Teknik-teknik analisis yang termasuk pada klasifikasi metode ini antara lain teknik analisis perbandingan, analisis persentase (indeks), analisis sumber dan penggunaan dana, analisis perubahan laba kotor. Metode analisis vertikal (statis) adalah metode analisis yang dilakukan dengan cara menganalisis laporan keuangan pada tahun (periode) tertentu, yaitu dengan membandingkan antara pos yang satu dengan pos yang lainnya pada laporan keuangan yang sama untuk tahun (periode) yang sama. Teknik-teknik analisis yang termasuk pada klasifikasi metode ini antara lain teknik analisis persentase per komponen (common size), analisis rasio dan analisis impas (Prastowo dan Juliaty, 2005)

Adapun tujuan dari penelitian ini adalah mengetahui persamaan fungsi produksi dengan pakan, benih dan tenaga kerja sebagai variabel bebas, mengetahui perkembangan neraca dan laporan laba-rugi perusahaan perseorangan Dobro selama kurun waktu tahun 2006-2009 dan menetapkan zona keberadaan perusahaan perseorangan Dobro berdasar formula Z" score.

\section{METODOLOGI PENELITIAN}

Metode penelitian yang digunakan adalah metode deskriptif analisis. Obyek penelitian adalah perusahaan perseorangan Dobro yang beralamat di dukuh Bulu RT 01/RW 04, desa Wonoharjo, kecamatan Kemusu, kabupaten Boyolali, propinsi Jawa Tengah.

Analisis pada penelitian ini menggunakan dua jenis data, yaitu:

1) Data primer yang berupa informasi perkembangan perusahaan dan diperoleh dari wawancara langsung dengan pemilik dan manajemen perusahaan.

2) Data sekunder yang berupa:

i. Data time series produksi setiap enam bulan pada tahun 20062009.

4 | Donny Suryanto dan Eko Sumartono, Analisis Finansial Usaha ... 
ii. Laporan laba rugi tahun 2006-2009.

iii. Neraca tahun 2006-2009.

Kedua jenis data tersebut dikumpulkan dengan cara wawancara, observasi, dokumentasi dan studi pustaka.

Analisis data pada penelitian ini terdiri dari:

\section{Analisis faktor-faktor yang mempengaruhi produksi}

Analisis ini menggunakan software statistik shazam windows version 8.0. Produksi budidaya ikan dirumuskan dengan persamaan regresi sebagai berikut:

$$
\operatorname{Ln} Y_{i}=b_{1}+b_{2} \operatorname{Ln} X_{2 i}+b_{3} \operatorname{Ln} X_{3 i}+b_{4} \operatorname{Ln} X_{4 i}+e_{i} \text {; }
$$

dimana Ln $Y_{i}$ adalah Jumlah produksi ikan (kg), $b_{1}$ adalah Konstanta, $b_{2}, b_{3}, b_{4}$ adalah Koefisien regresi, $\mathrm{i}$ adalah $1,2, \ldots . ., \mathrm{n}, \mathrm{Ln} \mathrm{X}_{2 \mathrm{i}}$ adalah Jumlah pakan yang digunakan untuk proses produksi $(\mathrm{kg}), \mathrm{Ln} \mathrm{X}_{3 \mathrm{i}}$ adalah Jumlah benih yang digunakan untuk proses produksi $(\mathrm{kg}), \mathrm{Ln} \mathrm{X}_{4 \mathrm{i}}$ adalah Jumlah tenaga kerja yang digunakan untuk produksi (jor), dan $\mathrm{e}_{\mathrm{i}}$ adalah Kesalahan random

\section{Analisis perbandingan laporan keuangan}

Analisis ini menggunakan angka indeks dengan formula:

$$
I=\frac{\sum P_{n}}{\sum P O} \times 100
$$

dimana I adalah Indeks, $\sum \mathrm{P}_{\mathrm{n}}$ adalah jumlah variabel yang dibandingkan pada tahun ke-n, dan $\sum \mathrm{P}_{0}$ adalah variabel yang dibandingkan pada tahun dasar.

\section{Analisis rasio keuangan}

Prihadi (2008) juga menjelaskan bahwa alat untuk menganalisis laporan keuangan perusahaan yang paling efektif adalah rasio keuangan (financial ratio). Horne dan Wachowicz (1997) menjelaskan bahwa laporan keuangan perusahaan terdiri dari neraca dan laporan rugi laba. Analisa rasio keuangan yang digunakan dalam penelitian ini meliputi:

\section{Rasio likuiditas}

Rasio likuiditas yang digunakan terdiri dari:

i. Rasio lancar (current ratio)

$$
\text { RasioLancar }=\frac{\text { AktivaLancar }}{\text { KewajibanLancar }}
$$


ISSN: 1412-8837

ii. Rasio sepat (quick ratio)

$$
\text { RasioLancar }=\frac{\text { AktivaLancar }- \text { Persediaan }}{\text { KewajibanLancar }}
$$

\section{Rasio solvabilitas (leverage ratio)}

Rasio solvabilitas yang akan dianalisis meliputi:

i. Rasio total hutang terhadap total aset (total debt to total asset ratio)

$$
\text { Total Debt to Total Asset }=\left(\frac{\text { Hutang Lancar }+ \text { Hutang jangkaPanjang }}{\text { JumlahAktiva }}\right) \times 100 \%
$$

ii. Rasio total hutang terhadap modal (total debt to total equity ratio)

$$
\text { TotalDebt to Equity Rasio }=\left(\frac{\text { Hutang Lancar }+ \text { Hutang jangkaPanjang }}{\text { JumlahModalSendiri }}\right) \times 100 \%
$$

Zilfikar Nazara (2005) melakukan penelitian bahwa analisis rasio keuangan selain dapat dipergunakan untuk mengetahui kinerja keuangan perusahaan, dapat dipergunakan sebagai alat penduga perubahan laba rugi pada perusahaan agribisnis. Adapun rumus yang digunakan menggunakan rasio efisiensi dan profitabilitas sebagai berikut:

\section{Rasio efisiensi}

Rasio efisiensi yang akan dianalisis meliputi:

i. Rasio perputaran persediaan (inventory turnover ratio)

$$
\text { PerputaranPersediaan }=\frac{\text { HargaPokokProduksi }}{\text { Persediaan }}
$$

ii. Rasio perputaran piutang (account receivable turnover ratio)

$$
\text { PerputaranPiutang }=\frac{\text { Penjualan }}{\text { Piutang }}
$$

iii. Rasio perputaran aktiva tetap (fixed asset turnover ratio)

$$
\text { PerputaranAktivaTetap }=\frac{\text { Penjualan }}{\text { AktivaTetap }}
$$

iv. Rasio perputaran total aktiva (total asset turnover ratio)

$$
\text { PerputaranTotal Aset }=\frac{\text { Penjualan }}{\text { Total Aktiva }}
$$

6 | Donny Suryanto dan Eko Sumartono, Analisis Finansial Usaha ... 


\section{Rasio profitabilitas (rentabilitas)}

Rasio profitabilitas yang dianalisis meliputi:

i. Marjin laba kotor (gross profit margin)

$$
\text { GrossProfitMargin }=\frac{\text { GrossProfit }}{\text { Sales }} \times 100 \%
$$

ii. Marjin laba operasi (operating profit margin)

$$
\text { OperatingProfitMargin }=\frac{\text { OperatingProfit }}{\text { Sales }} \times 100 \%
$$

iii. Marjin laba bersih (net profit margin)

$$
\text { NetProfitMargin }=\frac{\text { NetProfit }}{\text { Sales }} \times 100 \%
$$

ii. Pengembalian atas investasi (Return on Investment/ROI)

$$
\text { Returnon Investment }=\frac{\text { LabaBersih }}{\text { Total Aktiva }} \times 100 \%
$$

\section{Analisis keamanan usaha.}

Analisis ini menggunakan varian ke-3 dari Altman Z Score yang dikhususkan untuk menganalisis kebangkrutan pada perusahaan private non manufaktur dengan formula sebagai berikut:

$$
Z^{\prime \prime}=6,56\left(X_{1}\right)+3,26\left(X_{2}\right)+6,72\left(X_{3}\right)+1,05\left(X_{4}\right)
$$

dimana, $X_{1}$ adalah Rasio modal kerja (aktiva lancar - hutang lancar) terhadap total aktiva, $X_{2}$ adalah Rasio laba ditahan terhadap total aktiva, $X_{3}$ adalah ROI atau rasio laba bersih terhadap total aktiva, $\mathrm{X}_{4}$ adalah Rasio modal sendiri terhadap hutang. berikut:

Adapun tiga zona yang dikembangkan oleh Altman adalah sebagai

i.Z" score $>2,60$ berarti perusahaan tidak terancam kebangkrutan

ii.Z" score 1,1-2,6 berarti perusahaan berada pada daerah ketidakpastian iii.Z" score $<1,1$ berarti perusahaan terancam kebangkrutan

\section{Analisis sensitivitas}

Menurut Umar (2005) cara sederhana untuk mengubah besarnya variabel penting dalam analisis sensitivitas dapat dilakukan dengan terpisah atau dikombinasikan dalam beberapa kombinasi dengan persentase tertentu untuk menentukan tingkat kepekaan hasil perhitungan terhadap beberapa perubahanperubahan tersebut.

Dalam penelitian ini analisis sensitivitas dilakukan dalam tingkat persentase perubahan sebagai berikut: 
1. Perubahan kenaikan biaya variabel pakan setiap kelipatan $5 \%$ dengan asumsi faktor lain tetap .

2. Perubahan penurunan harga output setiap kelipatan $5 \%$ dengan asumsi faktor lain tetap.

3. Perubahan secara bersamaan antara kenaikan biaya variabel pakan dan penurunan harga output setiap kelipatan $5 \%$ dengan asumsi faktor lain tetap.

Pengujian sensitivitas pada tiga macam perubahan tersebut akan dihentikan pada persentase yang menyebabkan nilai Profitability Index sama dengan 1

\section{HASIL DAN PEMBAHASAN}

\section{Faktor-Faktor yang Mempengaruhi Produksi}

Berdasarkan analisis regresi linear berganda, faktor-faktor yang mempengaruhi produksi ikan di perusahaan perseorangan Dobro adalah seperti pada tebel 1.

\section{Tabel 2. Hasil Estimasi Model}

\begin{tabular}{lccr}
\hline \multicolumn{1}{c}{ Variabel Bebas } & Koefisien regresi & Tingkat Kesalahan & thitung $^{\text {The }}$ \\
\hline Konstanta & 1,0095 & 0,456 & 0,8237 \\
Pakan $\left(\operatorname{Ln} X_{2 i}\right)$ & $0,38366^{* *}$ & 0,030 & 3,310 \\
Benih $\left(\operatorname{Ln~X} X_{3 i}\right)$ & $0,17072 * *$ & 0,033 & 3,194 \\
Tenaga Kerja $\left(\operatorname{Ln~} X_{4 i}\right)$ & $0,45609 * * *$ & 0,004 & 6,012 \\
\hline
\end{tabular}

$\mathrm{R}^{2}=0,9864$

$\mathrm{F}_{\text {hitung }}=96,833(1 \%)$

Keterangan: ***signifikansi 1\%, ** signifikansi 5\%, * signifikansi 10\%, ts tidak signifikan, $\mathrm{F}_{\text {tabel }}(3,4)=16,69, \mathrm{t}_{\text {tabel }}(1 \%, 4)=3,747, \mathrm{t}_{\text {tabel }}(5 \%, 4)=2,132, \mathrm{t}_{\text {tabel }}(10 \%, 4)=1,533$

Hasil analisis pada Tabel 2 diketahui bahwa 98,64\% variasi produksi ikan dapat dijelaskan oleh variasi ketiga variabel independen yaitu pakan, benih dan tenaga kerja. Sedangkan sisanya $(100 \%-98,64 \%=1,36 \%)$ dijelaskan oleh faktorfaktor lain di luar model.

Untuk mengetahui apakah semua variabel independen (pakan, benih dan tenaga kerja) secara simultan berpengaruh terhadap variabel dependen (produksi) adalah membandingkan $\mathrm{F}_{\text {hitung }}$ dengan $\mathrm{F}_{\text {tabel }}$. $\mathrm{F}_{\text {tabel }}$ dari persamaan diatas adalah $\mathrm{F}(3,4)=16,69(1 \%)$, karena $\mathrm{F}_{\text {hitung }}(96,833)$ lebih besar dari $\mathrm{F}_{\text {tabel }}$ maka secara simultan semua variabel independen berpengaruh terhadap variabel dependen.

Untuk mengetahui apakah semua variabel independen (pakan, benih, dan tenaga kerja) secara individual berpengaruh terhadap variabel dependen (produksi) adalah membandingkan thitung dengan $t_{\text {tabel. }}$. Dari tabel 5 dapat

8 | Donny Suryanto dan Eko Sumartono, Analisis Finansial Usaha ... 


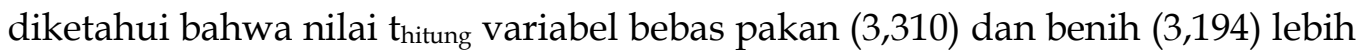
besar dari $t_{\text {tabel }(5 \%, 4)}$ yang bernilai 2,132. Hal ini berarti bahwa pada derajat signifikasi $5 \%$ variabel bebas pakan dan benih secara individual berpengaruh terhadap produksi. Sedangkan nilai $t_{\text {hitung variable bebas tenaga kerja adalah }}$ 6,012 dan nilai ini lebih besar dari $t_{\text {tabel }(1 \%, 4)}$ yang bernilai 3,747 . Hal ini menunjukkan bahwa pada derajat signifikasi $1 \%$, variabel bebas benih berpengaruh secara individual terhadap produksi.

Dapat diketahui pula dari koefisien regresi bahwa setiap kenaikan 1\% pemberian pakan maka akan meningkatkan produksi sebesar $0,38366 \%$ dan setiap kenaikan $1 \%$ penebaran benih akan meningkatkan produksi sebesar $0,17072 \%$. Kenaikan yang cukup signifikan pada produksi sebesar $0,45609 \%$ dapat dilakukan apabila jumlah jam orang kerja (jor) ditingkatkan sebesar $1 \%$.

\section{Analisis Perbandingan Laporan Keuangan}

Hasil analisis perbandingan laporan keuangan yang diperoleh dari neraca perusahaan tahun 2006 - 2009 disajikan pada Tabel 2.

\begin{tabular}{lrrrrrr}
$\begin{array}{l}\text { Tabel 3. } \begin{array}{c}\text { Perkembangan Indeks } \\
\text { Perseorangan Dobro }\end{array} \\
\text { Keterangan }\end{array}$ & \multicolumn{5}{c}{ Angka Indeks Nominal (\%) } & $\begin{array}{c}\text { Nilai Riil Neraca } \\
\text { Tahun 2006 } \\
\text { (TahunDasar) }\end{array}$ \\
\cline { 2 - 6 } & $\mathbf{2 0 0 6}$ & $\mathbf{2 0 0 7}$ & $\mathbf{2 0 0 8}$ & $\mathbf{2 0 0 9}$ & $\mathbf{2 0 0 9}$ & $\begin{array}{c}\text { Perusahaan } \\
\text { (Tahun }\end{array}$ \\
\hline Aktiva Lancar & 100.00 & 102.04 & 105.31 & 102.39 & $1,579,074,393$ \\
Aktiva Tetap & 100.00 & 114.49 & 107.97 & 99.23 & $594,621,910$ \\
Total Aktiva & 100.00 & 105.44 & 106.03 & 101.53 & $2,173,696,303$ \\
Kewajiban Lancar & 100.00 & 147.61 & 50.45 & 33.43 & $60,482,905$ \\
Kewajiban Jangka Panjang & 100.00 & 48.34 & 11.66 & 11.66 & $1,047,050,874$ \\
Ekuitas & 100.00 & 159.13 & 201.87 & 193.64 & $1,066,162,524$ \\
Total Kewajiban dan Ekuitas & 100.00 & 105.44 & 106.03 & 101.53 & $2,173,696,303$ \\
\hline
\end{tabular}

Dari Tabel 3, aktiva lancar mempunyai kecenderungan meningkat, akan tetapi peningkatannya tidak terlalu besar. Kecilnya peningkatan aktiva lancar ini sangat dipengaruhi oleh kenaikan piutang usaha dan kas/setara kas yang diiringi dengan program penurunan persediaan yang menyesuaikan kemampuan cashflow perusahaan untuk menghindari penambahan hutang.

Kecilnya penurunan aktiva tetap terjadi karena besarnya penyusutan dapat diimbangi dengan bertambahnya nilai aktiva tetap pada tahun 2007 dan 2008 karena pembelian aset armada penjualan dan peralatan pendukung. Sementara total aktiva hanya sedikit mengalami kecenderungan meningkat mengikuti pola tren dari aktiva tetap. Hal ini menunjukkan aset perusahaan memiliki kestabilan setiap tahunnya. 
Tabel 4. Perkembangan Indeks Laporan Laba Rugi Tahun 2006 - 2009 Perusahaan Perseorangan Dobro

\begin{tabular}{|c|c|c|c|c|c|}
\hline \multirow{2}{*}{ Keterangan } & \multicolumn{4}{|c|}{ Indeks Nominal (\%) } & \multirow{2}{*}{$\begin{array}{l}\text { Nilai Riil Laba } \\
\text { Rugi Tahun } 2006 \\
\text { (Tahun Dasar) }\end{array}$} \\
\hline & 2006 & 2007 & 2008 & 2009 & \\
\hline Penjualan & 100.00 & 119.26 & 101.98 & 75.19 & $6,567,420,650$ \\
\hline Harga Pokok Penjualan & 100.00 & 125.72 & 102.56 & 81.97 & $5,298,779,299$ \\
\hline Laba Kotor & 100.00 & 92.29 & 99.57 & 46.90 & $1,268,641,351$ \\
\hline Beban Usaha & 100.00 & 118.38 & 148.82 & 108.53 & $413,312,641$ \\
\hline Laba Usaha & 100.00 & 79.68 & 75.77 & 17.12 & $855,328,710$ \\
\hline Pendapatan Lain-Lain & 100.00 & 41.06 & 50.39 & 19.35 & $7,928,470$ \\
\hline Beban Lain-Lain & 0.00 & 0.00 & 0.00 & 0.00 & 0 \\
\hline Laba Sebelum Pajak & 100.00 & 79.32 & 75.54 & 17.14 & $863,257,180$ \\
\hline Pajak Penghasilan & 0.00 & 0.00 & 0.00 & 0.00 & 0 \\
\hline Laba Sebelum Zakat & 100.00 & 79.32 & 75.54 & 17.14 & $863,257,180$ \\
\hline Zakat & 100.00 & 169.76 & 167.86 & 23.43 & $15,787,171$ \\
\hline Laba Bersih & 100.00 & 77.64 & 73.82 & 17.02 & $847,470,009$ \\
\hline
\end{tabular}

Pada tahun 2009, jumlah kewajiban lancar yang berupa hutang terhadap petani ikan mengalami penurunan hingga $66,57 \%$ dari nilainya pada tahun dasar. Selain itu, perusahaan juga mampu menurunkan kewajiban jangka panjangnya yang berupa hutang terhadap perusahaan pakan ikan dimana pada akhir tahun 2009, perusahaan mampu menurunkan kewajibannya hingga $88,34 \%$ dari nilainya pada tahun dasar. Penurunan kewajiban ini sebagian besar menggunakan laba yang ditahan perusahaan setiap akhir periode. Ekuitas memiliki peningkatan yang tinggi. Tercatat pada tahun 2009, nilai ekuitas telah meningkat sebanyak 93,64\% dari nilainya pada tahun dasar. Peningkatan ini didorong oleh laba ditahan yang cukup besar setiap tahunnya.

Penjualan yang dibukukan perusahaan perseorangan Dobro selama empat tahun terakhir berasal dari penjualan ikan $(72,75 \%)$, penjualan pakan $(23,38 \%)$, penjualan benih $(3,74 \%)$ dan penjualan bahan penunjang berupa oksigen $(0,11 \%)$ dan obat-obatan berupa Enrofloxacine $\mathrm{HCl}(0,02 \%)$. Dari tabel 3 dapat diketahui bahwa penjualan dan harga pokok penjualan (HPP) mengalami penurunan drastis pada tahun 2009 dengan nilai penurunan masing-masing 24,81\% dan $18,03 \%$ dari tahun dasar. Hal ini disebabkan oleh lemahnya permintaan pasar yang diduga karena pengaruh krisis ekonomi global yang terjadi sejak November 2008. Peningkatan penjualan secara temporer pada tahun 2007 disebabkan karena meningkatnya persediaan ikan di petani ikan karena pada tahun tersebut kemampuan petani dalam memproduksi ikan meningkat karena terdapat bantuan modal dari perbankan.

10 | Donny Suryanto dan Eko Sumartono, Analisis Finansial Usaha ... 
Beban usaha meningkat tajam pada tahun 2008 sebesar 48,82\% dari tahun dasar. Hal ini disebabkan oleh kebijakan perusahaan untuk memberikan bonus yang cukup besar kepada karyawan dan memindahkan beban biaya pemanenan sebesar Rp. 150/kg yang semula menjadi tanggung jawab pedagang kemudian pada tahun 2008 menjadi tanggung jawab perusahaan. Hal ini dilakukan manajemen untuk menambah daya saing produknya di pasar karena mulai banyaknya kompetitor baru. Penjualan rendah pada tahun 2009 telah menyebabkan perusahaan mengalami kesulitan cashflow dan mengakibatkan penurunan laba bersih pada tahun 2009 yang hanya mencapai angka 17,02\% dari pencapaiannya pada tahun dasar.

\section{Analisis Rasio}

Hasil analisis rasio disajikan pada Tabel 5. Secara umum dapat dikatakan bahwa rasio likuiditas mengalami peningkatan yang tajam. Rasio lancar dan cepat masing-masing memiliki nilai rata-rata 44,65 kali dan 31,25 kali dengan rata-rata peningkatan per tahun masing-masing 17,95 kali dan 14,56 kali. Hal ini menunjukkan perusahaan mampu memperbaiki kemampuannya dalam menjamin setiap kewajiban lancar dengan aktiva lancar yang dimiliknya.

Rasio solvabilitas mengalami penurunan yang tajam pula. Rasio hutang terhadap total aktiva dan rasio hutang terhadap modal sendiri masing-masing memiliki nilai rata-rata $22,50 \%$ dan $38,24 \%$ dengan rata-rata penurunan per tahun masing-masing $14,83 \%$ dan $32,33 \%$. Hal ini menunjukkan perusahaan juga mampu memperbaiki kemampuannya dalam membayar kewajiban. Kedua nilai rasio ini menunjukkan bahwa perusahaan sangat solvable. Menurunnya rasio likuiditas dan solvabilitas merupakan dampak positif dari penahanan sebagian besar laba untuk penurunan kewajiban perusahaan.

Sedikit masalah pada efisiensi atau aktivitas perusahaan dapat ditunjukkan dengan rendahnya nilai rasio perputaran total aktiva yang hanya 2,90 kali pada tahun 2009. Kemudian dapat dilihat juga dari tingkat penurunannya per tahun pada rasio perputaran piutang (1,04 kali), perputaran aktiva tetap $(0,89$ kali) dan perputaran total aktiva $(0,26$ kali). Kedua masalah tersebut menunjukkan bahwa perusahaan mengalami penurunan tingkat efisiensi setiap tahun walaupun secara umum perusahaan masih cukup efisien hingga akhir tahun 2009. Karena seluruh jenis rasio efisiensi berbanding lurus dengan penjualan maka dapat diketahui bahwa perusahaan sedang mengalami masalah dalam hal penjualan produknya.

Rasio profitabilitas masih memiliki nilai rata-rata yang bagus. Akan tetapi terjadi penurunan yang tajam. Hal ini ditunjukkan dengan rata-rata penurunan per tahun pada gross profit margin, operating profit margin, net profit margin dan return on investment sebesar 2,42\%, 3,38\%, 3,33\% dan 10,82\%. Penurunan tingkat profitabilitas ini disebabkan oleh menurunnya tingkat 
penjualan karena efek krisis global terhadap permintaan pasar, bertambahnya kompetitor dan kenaikan beban usaha.

Tabel 5. Analisis rasio laporan keuangan perusahaan perseorangan Dobro tahun 2006-2009

\begin{tabular}{|c|c|c|c|c|c|}
\hline \multirow{2}{*}{ Analisis Rasio } & \multicolumn{4}{|c|}{ Nilai dan Pertumbuhan Tiap Tahun } & \multirow{2}{*}{ Rata rata } \\
\hline & 2006 & 2007 & 2008 & 2009 & \\
\hline \multicolumn{6}{|l|}{ Rasio Likuiditas } \\
\hline Rasio Lancar (kali) & $\begin{array}{r}26.11 \\
(-8.06)\end{array}$ & $\begin{array}{r}18.05 \\
(36.44)\end{array}$ & $\begin{array}{r}54.49 \\
(25.48)\end{array}$ & 79.97 & $\begin{array}{r}44.65 \\
(17.95)\end{array}$ \\
\hline Rasio Cepat (kali) & $\begin{array}{r}15.72 \\
(-3.27)\end{array}$ & $\begin{array}{r}12.45 \\
(24.98)\end{array}$ & $\begin{array}{r}37.44 \\
(21.97)\end{array}$ & 59.40 & $\begin{array}{r}31.25 \\
(14.56)\end{array}$ \\
\hline \multicolumn{6}{|l|}{ Rasio Solvabilitas } \\
\hline Total Debt to Total Asset Ratio(\%) & $\begin{array}{r}50.95 \\
(-24.97)\end{array}$ & $\begin{array}{r}25.98 \\
(-19.35)\end{array}$ & $\begin{array}{r}6.62 \\
(-0.17)\end{array}$ & 6.45 & $\begin{array}{r}22.50 \\
(-14.83)\end{array}$ \\
\hline Total Debt to Equity Ratio(\%) & $\begin{array}{r}103.8 \\
(-68.79)\end{array}$ & $\begin{array}{r}35.09 \\
(-28.00)\end{array}$ & $\begin{array}{r}7.09 \\
(-0.20)\end{array}$ & 6.89 & $\begin{array}{r}38.24 \\
(-32.33)\end{array}$ \\
\hline \multicolumn{6}{|l|}{ Rasio Efisiensi } \\
\hline Inventory Turnover (kali) & $\begin{array}{r}8.43 \\
(4.90)\end{array}$ & $\begin{array}{r}13.34 \\
(-2.89)\end{array}$ & $\begin{array}{l}10.44 \\
(0.00)\end{array}$ & 10.44 & $\begin{array}{l}10.66 \\
(0.67)\end{array}$ \\
\hline Account Receivable Turnover (kali) & $\begin{array}{r}7.96 \\
(0,42)\end{array}$ & $\begin{array}{r}8.38 \\
(-1.59)\end{array}$ & $\begin{array}{r}6.79 \\
(-1.97\end{array}$ & 4.83 & $\begin{array}{r}6.99 \\
(-1.04)\end{array}$ \\
\hline Fixed Asset Turnover (kali) & $\begin{array}{l}11.04 \\
(0.46)\end{array}$ & $\begin{array}{r}11.50 \\
(-1.70)\end{array}$ & $\begin{array}{l}10.43 \\
(-2.06\end{array}$ & 8.37 & $\begin{array}{r}10.34 \\
(-0.89)\end{array}$ \\
\hline Total Asset Turnover (kali) & $\begin{array}{r}3.02 \\
(0,40)\end{array}$ & $\begin{array}{r}3.42 \\
(-0,51)\end{array}$ & $\begin{array}{r}2.91 \\
(-0.67\end{array}$ & 2.24 & $\begin{array}{r}2.90 \\
(-0.26)\end{array}$ \\
\hline \multicolumn{6}{|l|}{ Rasio Profitabilitas } \\
\hline Gross Profit Margin (\%) & $\begin{array}{r}19.32 \\
(-4.37)\end{array}$ & $\begin{array}{l}14.95 \\
(3.91)\end{array}$ & $\begin{array}{r}18.86 \\
(-6.81)\end{array}$ & 12.05 & $\begin{array}{r}16.29 \\
(-2.42)\end{array}$ \\
\hline Operating Profit Ratio (\%) & $\begin{array}{r}13.14 \\
(-4.40)\end{array}$ & $\begin{array}{r}8.74 \\
(0.99)\end{array}$ & $\begin{array}{r}9.74 \\
(-6.74)\end{array}$ & 3.00 & $\begin{array}{r}8.65 \\
(-3.38)\end{array}$ \\
\hline Net Profit Margin (\%) & $\begin{array}{r}12.90 \\
(-4.50)\end{array}$ & $\begin{array}{r}8.40 \\
(0.94)\end{array}$ & $\begin{array}{r}9.34 \\
(-6.42)\end{array}$ & 2.92 & $\begin{array}{r}8.39 \\
(-3.33)\end{array}$ \\
\hline Return on Investment (\%) & $\begin{array}{r}38.99 \\
(-10.28) \\
\end{array}$ & $\begin{array}{r}28.71 \\
(-1.56) \\
\end{array}$ & $\begin{array}{r}27.14 \\
(-20.61) \\
\end{array}$ & 6.54 & $\begin{array}{r}25.34 \\
(-10.82) \\
\end{array}$ \\
\hline
\end{tabular}

Sumber : Dobro Company 2011

\section{Analisis Keamanan Usaha}

Keamanan usaha diukur dengan menggunakan analisis Altman Z" score. Hasil estimasi disajikan pada Tabel 6. Berdasarkan Tabel 6 dapat diketahui bahwa Z" score rata-rata perusahaan masih diatas 2,60\% sehingga dapat dikatakan bahwa perusahaan aman dari ancaman kebangkrutan.

12 | Donny Suryanto dan Eko Sumartono, Analisis Finansial Usaha ... 
Tabel 6. Analisis Altman Z" Score

\begin{tabular}{lrrrrr}
\hline \multirow{2}{*}{ Hasil Analisis } & \multicolumn{4}{c}{ Tahun } & Rata-rata \\
\cline { 2 - 5 } & $\mathbf{2 0 0 6}$ & $\mathbf{2 0 0 7}$ & $\mathbf{2 0 0 8}$ & $\mathbf{2 0 0 9}$ & \\
\hline Rasio Modal Kerja terhadap Total Aktiva & 0.70 & 0.66 & 0.71 & 0.72 & 0.70 \\
Rasio Laba Ditahan terhadap Total Aktiva & 0.39 & 0.28 & 0.20 & -0.04 & 0.21 \\
Return on Investment & 0.39 & 0.29 & 0.27 & 0.07 & 0.25 \\
Rasio Modal Sendiri terhadap Total Hutang & 0.96 & 2.85 & 14.10 & 14.50 & 8.10 \\
\hline Hasil Altman Z" Score & $\mathbf{9 . 4 8}$ & $\mathbf{1 0 . 1 7}$ & $\mathbf{2 1 . 9 2}$ & $\mathbf{2 0 . 2 8}$ & $\mathbf{1 5 . 4 7}$ \\
\hline
\end{tabular}

\section{SIMPULAN DAN SARAN}

Berdasarkan hasil penelitian yang dilakukan pada perusahaan perseorangan Dobro dapat disimpulkan bahwa:

1. Produksi ikan perusahaan perseorangan Dobro dipengaruhi oleh pakan, benih dan tenaga kerja baik secara bersama-sama atau secara individual. Berdasarkan hasil regresi diketahui bahwa variabel bebas tenaga kerja memiliki pengaruh yang paling signifikan.

2. Berdasarkan analisis rasio keuangan didapatkan hal-hal sebagai berikut:

a. Perusahaan memiliki kemampuan yang baik dalam membayar kewajiban jangka pendeknya.

b. Kemampuan perusahaan dalam memenuhi seluruh kewajibannya terus mengalami peningkatan.

c. Secara umum efisiensi (aktivitas) perusahaan memiliki tingkat perputaran yang cukup bagus walaupun seluruh indikator perputaran memiliki kecenderungan menurun.

d. Tingkat profitabilitas perusahaan cukup tinggi. Akan tetapi kecenderungan penurunannya juga cukup tinggi .

3. Perusahaan masih berada pada zona aman dari ancaman kebangkrutan berdasarkan perhitungan nilai Z" score.

\section{DAFTAR PUSTAKA}

Darmawi. 2005. Analisis Kinerja Unit Simpan Pinjam Swamitra Koperasi Unit Desa Godean Kabupaten Sleman. Tesis MMA. Universitas Gadjah Mada. Yogyakarta

Gill, J. O. dan M. Chatton. 1999. Understanding Financial Statements. Dwi Prabaningtyas (Penterjemah, 2008). Memahami Laporan Keuangan. Penerbit PPM. Jakarta. ix +120

Horne, C. V. dan J. M. Wachowicz. 1997. Prinsip-Prinsip Manajemen Keuangan. Salemba Empat. Jakarta. $\mathrm{xi}+320$ 
Khairuman dan D. Sudenda. 2002. Budidaya Patin secara Intensif. PT. Agro Media Pustaka. Depok. ix+89

Munawir, S. 2002. Akuntansi Keuangan dan Manajemen. Edisi Pertama. Badan Penerbit Fakultas Ekonomi. Yogyakarta

Munawir, S. 2004. Analisa Laporan Keuangan. Edisi Keempat. Penerbit Liberty. Yogyakarta.

Nazara dan Zulfikar. 2005. Analisis Rasio Keuangan sebagai Penduga Perubahan Laba/Rugi pada Perusahaan Agribisnis di BEJ Surabaya. Tesis MMA. Universitas Gadjah Mada. Yogyakarta

Prastowo, D. P. dan Juliaty, R. 2005. Analisis Laporan Keuangan Konsep dan Aplikasi. Edisi Kedua. UPP AMP YKPN. Yogyakarta.

Prihadi, Toto. 2008. Deteksi Cepat Kondisi Keuangan: 7 Analisis Rasio Keuangan. Penerbit PPM. Jakarta. vi+182

Proyek Pengkajian Teknologi Pertanian Yogyakarta. 1997. Budidaya Ikan Dalam Karamba Jaring Apung. Instalasi Penelitian dan Pengkajian Teknologi Pertanian IP2TP. Yogyakarta. iii +30

Suciyati, H. 2005. Strategi Pemasaran Nila Merah Hasil Budidaya Sistem Karamba Jaring Apung di Kabupaten Sragen. Tesis. Program Studi Magister Manajemen Agribisnis, Fakultas Pertanian, Universitas Gadjah Mada. Yogyakarta. xiii+76

Swasta, B. 1995. Pengantar Bisnis Modern, Pengantar Ekonomi Perusahaan Modern. Edisi Kelima. Liberty. Yogyakarta

Tim Peneliti Perikanan UGM. 1992. Study/Penelitian Perikanan di Waduk Kedung Ombo. Jurusan Perikanan, Fakultas Pertanian Universitas Gadjah Mada. Yogyakarta. xxxix+287

Umar, H. 2003. Metode Penelitian untuk Skripsi dan Tesis. Cetakan Kelima. Grafindo Persada. Jakarta.

14 | Donny Suryanto dan Eko Sumartono, Analisis Finansial Usaha ... 